\title{
Volcanic hazards to airports
}

\author{
Marianne Guffanti · Gari C. Mayberry • Thomas J. Casadevall • \\ Richard Wunderman
}

Received: 28 September 2007/ Accepted: 7 May 2008/Published online: 4 June 2008

(C) Springer Science+Business Media B.V. 2008

\begin{abstract}
Volcanic activity has caused significant hazards to numerous airports worldwide, with local to far-ranging effects on travelers and commerce. Analysis of a new compilation of incidents of airports impacted by volcanic activity from 1944 through 2006 reveals that, at a minimum, 101 airports in 28 countries were affected on 171 occasions by eruptions at 46 volcanoes. Since 1980, five airports per year on average have been affected by volcanic activity, which indicates that volcanic hazards to airports are not rare on a worldwide basis. The main hazard to airports is ashfall, with accumulations of only a few millimeters sufficient to force temporary closures of some airports. A substantial portion of incidents has been caused by ash in airspace in the vicinity of airports, without accumulation of ash on the ground. On a few occasions, airports have been impacted by hazards other than ash (pyroclastic flow, lava flow, gas emission, and phreatic explosion). Several airports have been affected repeatedly by volcanic hazards. Four airports have been affected the most often and likely will continue to be among the most vulnerable owing to continued nearby volcanic activity: Fontanarossa International Airport in Catania, Italy; Ted Stevens Anchorage International Airport in Alaska, USA; Mariscal Sucre International Airport in Quito, Ecuador; and Tokua Airport in Kokopo, Papua New Guinea. The USA has the most airports affected by volcanic activity (17) on the most occasions (33) and hosts the second highest number of volcanoes that have caused the disruptions (5, after Indonesia with 7). One-fifth of the affected airports are within $30 \mathrm{~km}$ of the source volcanoes, approximately half are located within $150 \mathrm{~km}$ of the source volcanoes, and about three-quarters are within $300 \mathrm{~km}$; nearly one-fifth are located more than $500 \mathrm{~km}$
\end{abstract}

M. Guffanti $(\bowtie)$

U.S. Geological Survey, Reston, VA 20192, USA

e-mail: guffanti@usgs.gov

G. C. Mayberry

U.S. Geological Survey, Washington, DC 20560, USA

T. J. Casadevall

U.S. Geological Survey, Denver, CO 80225, USA

R. Wunderman

Smithsonian Institution, Washington, DC 20560, USA 
away from the source volcanoes. The volcanoes that have caused the most impacts are Soufriere Hills on the island of Montserrat in the British West Indies, Tungurahua in Ecuador, Mt. Etna in Italy, Rabaul caldera in Papua New Guinea, Mt. Spurr and Mt. St. Helens in the USA, Ruapehu in New Zealand, Mt. Pinatubo in the Philippines, and Anatahan in the Commonwealth of the Northern Mariana Islands (part of the USA). Ten countries-USA, Indonesia, Ecuador, Papua New Guinea, Italy, New Zealand, Philippines, Mexico, Japan, and United Kingdom-have the highest volcanic hazard and/or vulnerability measures for airports. The adverse impacts of volcanic eruptions on airports can be mitigated by preparedness and forewarning. Methods that have been used to forewarn airports of volcanic activity include real-time detection of explosive volcanic activity, forecasts of ash dispersion and deposition, and detection of approaching ash clouds using ground-based Doppler radar. Given the demonstrated vulnerability of airports to disruption from volcanic activity, at-risk airports should develop operational plans for ashfall events, and volcano-monitoring agencies should provide timely forewarning of imminent volcanic-ash hazards directly to airport operators.

Keywords Volcanic hazards · Volcanic ash · Airports · Volcanic-risk mitigation

\section{Introduction}

The threat to en-route aircraft from airborne volcanic-ash clouds is widely recognized (Miller and Casadevall 2000), with more than 100 encounters of aircraft with ash clouds occurring since 1973 (Guffanti et al. 2004). A less notorious but also significant threat to aviation from volcanic activity comprises operational disruption and physical damage at airports. To characterize the nature and scope of volcanic hazards to airports, we collected data on incidents of airports worldwide that have been affected by volcanic activity. The data begin in 1944-with the first documented instance of damage to modern aircraft and facilities in Naples, Italy, from an eruption of Vesuvius-and extend through 2006. Information was gleaned from various sources, including news outlets, volcanological reports (particularly the Smithsonian Institution's Bulletin of the Global Volcanism Network), and previous publications on the topic (primarily Blong 1984; Casadevall 1993).

For each incident, information about the affected airport and the volcanic source has been compiled as a record in a database. The database is not a complete inventory because incidents are not always reported or documented, but it does present a good sample from around the world. Not included are en-route diversions to avoid airborne ash clouds at cruise altitudes. The database fields are airport name and jurisdiction (city, town, or military base); country in which the airport is located; airport location as latitude and longitude (in decimal degrees); name and country of the source volcano and its location as latitude and longitude (in decimal degrees); date and Volcanic Explosivity Index (VEI) of the eruptive activity that caused the incident; calculated distance of the airport from the volcanic source; type of hazard (ashfall, airborne ash, pyroclastic flow, lava flow, phreatic explosion); number of days the airport may have been closed (if known); a brief summary of the effect; and data references. The complete database is published in Guffanti et al. (2007), http://pubs.usgs.gov/of/2007/1256/.

In addition to characterizing the volcanic hazard to airports in this article, we also discuss some methods that have been used to mitigate adverse effects at airports. Experience has shown that adverse effects can be lessened and that affected airports can operate 
with due caution. We also report limited economic data on some of the costs incurred as a result of volcanic hazards.

\section{Characteristics of volcanic hazards to airports}

Analysis of the database by Guffanti et al. (2007) reveals that, at a minimum, 101 airports in 28 countries (Fig. 1) were impacted on 171 occasions from 1944 through 2006 by eruptions at 46 volcanoes. The number of affected airports (101) probably is better constrained than the number of incidents (171) because recurring disruptions at a given airport may have been lumped together or not reported by news agencies, whereas the initial disruption is more likely to be noticed and reported, and thus, the airport correctly counted. Table 1 is a list of the 101 cities, towns, and military bases in which airports have been impacted, organized by country.

\subsection{Types of volcanic hazards to aviation}

The types of hazardous volcanic activity that have affected airports are ashfall, ash in airspace around airports, lava flows, pyroclastic flows, gas emission, and phreatic explosion.

The primary hazard to airports is ashfall, which can cause loss of visibility, create slippery runways, infiltrate communication and electrical systems, interrupt ground services, and damage buildings and parked airplanes. The documented thicknesses of ash accumulation at airports vary from a few millimeters to several centimeters. The amount of accumulated ash depends primarily on the size of the eruption, the wind field that disperses the ash, and the distance of the airport from the volcanic source. The maximum documented accumulation at an airport, $50 \mathrm{~cm}$, occurred at Rabaul Airport which lies only $7 \mathrm{~km}$ from the volcanic source. Major ash accumulation also resulted from the very large 1991 eruption of Mt. Pinatubo in the Philippines (second largest eruption in the twentieth century) which deposited $15-20 \mathrm{~cm}$ of ash at airports $20-40 \mathrm{~km}$ distant from the volcano

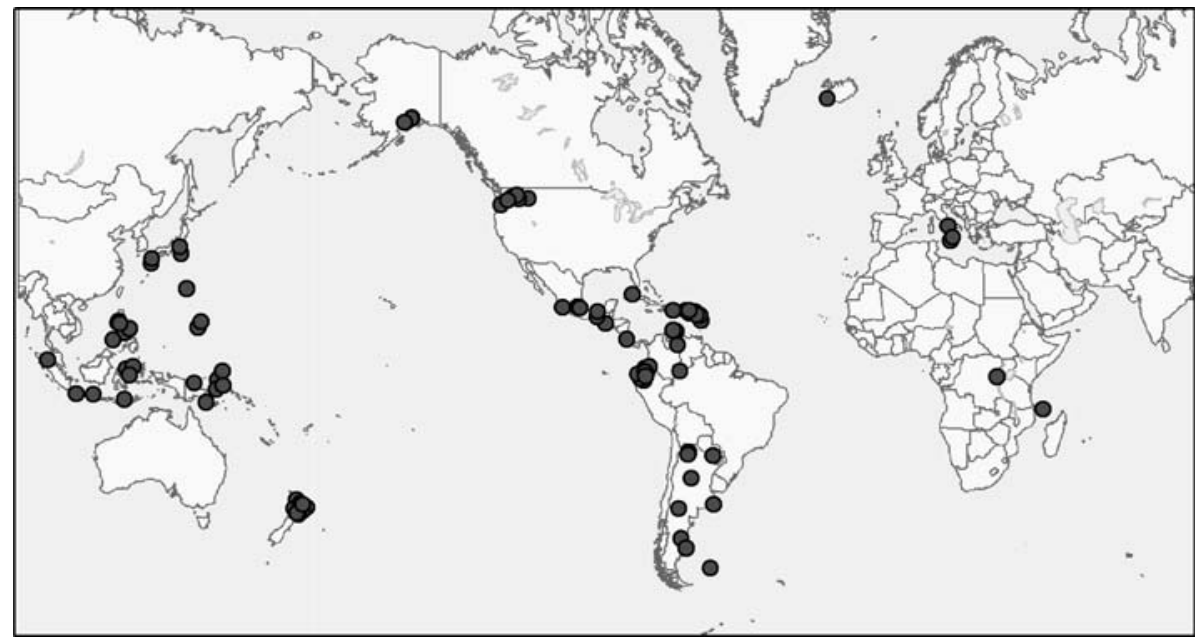

Fig. 1 Map showing locations of airports impacted by volcanic activity, 1944-2006 
Table 1 List of cities, towns, and military bases in which airports were affected by volcanic activity, 1944 through 2006, organized by country. N1 is number of airports that have been affected in each country. The number in parentheses after each airport locale is the number of documented incidents at that site. N2 is total of incidents at all airports in each country

\begin{tabular}{|c|c|c|c|}
\hline Country & N1 & Locale & $\mathrm{N} 2$ \\
\hline Antigua & 1 & Saint John's (1) & 1 \\
\hline Argentina & 8 & $\begin{array}{l}\text { Comodoro Rivadavia (1), Cordoba (1), Jujuy (1), Mar del Plata (1), } \\
\text { Neuquen (1), Puerto Deseado (1), Puerto Julian (1), Salta (1) }\end{array}$ & 8 \\
\hline Colombia & 1 & Pasto (2) & 2 \\
\hline Comoros & 1 & Moroni (1) & 1 \\
\hline Costa Rica & 1 & San Jose (1) & 1 \\
\hline Cuba & 1 & Havana (1) & 1 \\
\hline $\begin{array}{l}\text { Democratic Republic } \\
\text { of the Congo }\end{array}$ & 1 & Goma (1) & 1 \\
\hline Dominica & 1 & Roseau (1) & 1 \\
\hline Dominican Republic & 1 & Santo Domingo (1) & 1 \\
\hline Ecuador & 7 & $\begin{array}{l}\text { Ambato (3), Cuenca (1), Guayaquil (2), Latacunga (1), Manta (1), } \\
\text { Quito (5), Riobamba (2) }\end{array}$ & 15 \\
\hline France (Guadeloupe) & 2 & Unspecified airport (2) & 2 \\
\hline Guatemala & 1 & Guatemala City (4) & 4 \\
\hline Iceland & 1 & Reykjavik (1) & 1 \\
\hline Indonesia & 8 & $\begin{array}{l}\text { Bandung (4), Gorontola (1), Manado (3), Maumere (1), Medan (1), } \\
\text { Sangihe (1), Surabaya (1), unspecified airport west of Gamalama } \\
\text { volcano (1) }\end{array}$ & 13 \\
\hline Italy & 4 & $\begin{array}{l}\text { Catania (7), Naples (1), Reggio di Calabria (1), Sigonella Naval Air } \\
\text { Station (3) }\end{array}$ & 12 \\
\hline Japan & 5 & $\begin{array}{l}\text { Iwo-jima (1), Kagoshima (3), Kumamoto (1), Mijake-jima (2), } \\
\text { Yokota Air Base (1) }\end{array}$ & 8 \\
\hline Mexico & 5 & $\begin{array}{l}\text { Colima (2), Mexico City (3), Puebla (1), Tuxtla Guitierrez (1), } \\
\text { Villahermosa (1) }\end{array}$ & 8 \\
\hline Netherlands Antilles & 2 & Curacao (1), Sint Maarten (2) & 3 \\
\hline Netherlands (Aruba) & 1 & Oranjestad (1) & 1 \\
\hline New Zealand & 11 & $\begin{array}{l}\text { Auckland (1), Gisborne (2), Hamilton (2), Napier (2), } \\
\text { New Plymouth (1), Palmerston N (2), Rotorua (2), Taupo (2), } \\
\text { Tauranga (3), Wanganui (2), Whakatane (2) }\end{array}$ & 21 \\
\hline Papua New Guinea & 6 & $\begin{array}{l}\text { Boram (1), Kavieng (1), Kimbe (1), Kokopo (6), Port Moresby (1), } \\
\text { Rabaul (1) }\end{array}$ & 11 \\
\hline Paraguay & 1 & Asuncion (1) & 1 \\
\hline Philippines & 8 & $\begin{array}{c}\text { Basa Air Base (1), Clark Air Base (1), Cubi Point Naval } \\
\text { Air Station (1), Kalibo (1), Legaspi (4), Manila (2), } \\
\text { Puerto Princesa (1), Sangley Point Air Base (1) }\end{array}$ & 12 \\
\hline Russia & 1 & Ust-Kamchatka (1) & 1 \\
\hline St. Kitts & 1 & St. Kitts AP (1) & 1 \\
\hline $\begin{array}{l}\text { United Kingdom (and } \\
\text { territories) }\end{array}$ & 3 & $\begin{array}{l}\text { Unspecified airport on Anguilla (1), Plymouth on Montserrat (4), } \\
\text { Stanley in Falkland Islands (1) }\end{array}$ & 6 \\
\hline $\begin{array}{l}\text { USA (and trusts and } \\
\text { commonwealths) }\end{array}$ & 17 & $\begin{array}{l}\text { Anchorage (7), Elmendorf Air Force Base (2), Fairchild Air Force } \\
\text { Base (1), Guam (1), Kenai (2), Merrill Field (2), Missoula (1), } \\
\text { Moses Lake (1), Portland (2), Pullman (1), Roosevelt Roads Naval } \\
\text { Air Station, Puerto Rico (1), Saipan, N. Mariana Islands (4), San Juan, } \\
\text { Puerto Rico (3), St. Croix, US Virgin Islands (1), St. Thomas, } \\
\text { US Virgin Islands (2), Spokane (1), Yakima (1) }\end{array}$ & 33 \\
\hline
\end{tabular}


Table 1 continued

\begin{tabular}{lrrr}
\hline Country & N1 & Locale & N2 \\
\hline Venezuela & 1 & Caracas (1) & 1 \\
Total & 101 & Total & 171 \\
\hline
\end{tabular}

(Casadevall et al. 1996). In most instances, however, accumulation is on the order of a centimeter or less, amounts sufficient to have caused temporary airport closures lasting hours to several days. For example, in Quito, Ecuador, the international airport was closed for 3 days as a result of deposition of $2-3 \mathrm{~mm}$ of ash from the October 1999 eruption of Guagua Pichincha about $15 \mathrm{~km}$ west of Quito and for 8 days as a result of deposition of 3-5 mm of ash from the November 2002 eruption of Reventador about $90 \mathrm{~km}$ east of Quito (Fig. 2).

Ash accumulation of more than a trace amount requires removal of the ash for airports to resume full operations. Ash does not simply disappear (like melting snow) or blow away but must be disposed of in a manner that prevents it from being remobilized by wind and aircraft and during the clean-up process itself. Case studies of clean-up methods used by several airports that have been affected by ashfall are given in Casadevall (1993). Various methods have been used depending on the amount of ash accumulation and the characteristics of the ash, as well as the type of equipment available. A set of recommended procedures for the protection and clean-up of ash-contaminated airports is given by the International Civil Aviation Organization (2001).

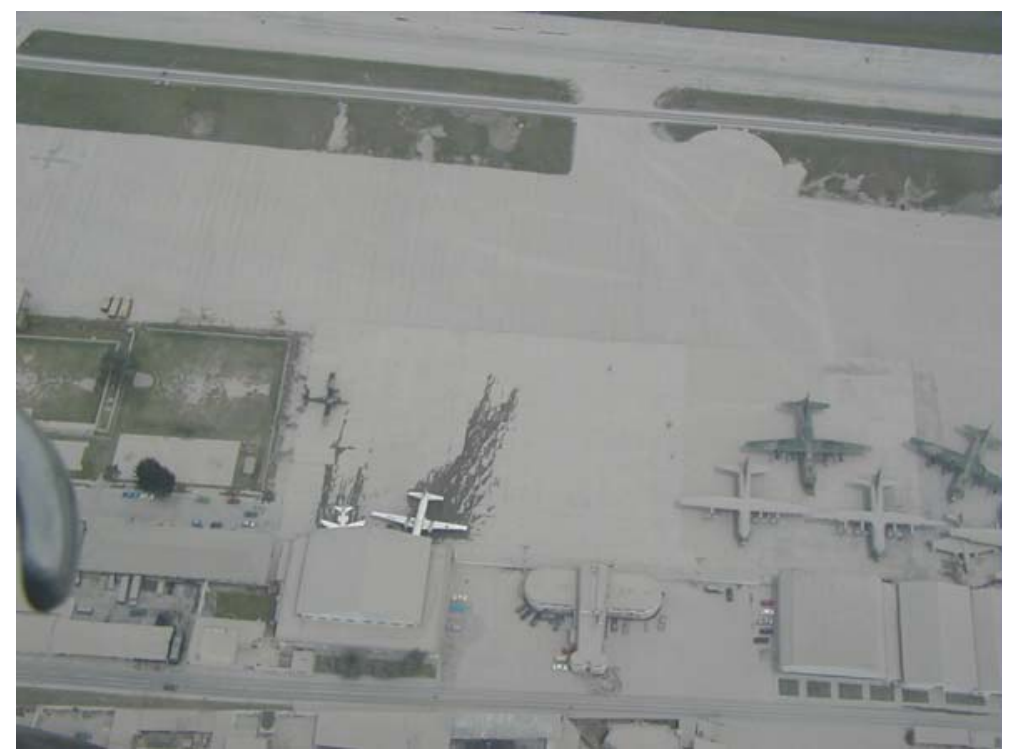

Fig. 2 Photograph taken from the air of volcanic ash from the 3 November 2002 eruption of Reventador covering surfaces at Mariscal Sucre International Airport in Quito. The airport was closed for 8 days as a result of 3-5 mm of ash deposition on planes and runways. Source: Photo by Hugo Yepes, Geophysical Institute of Ecuador 
In about one-fifth of the compiled incidents noticeable ash accumulation did not occur, but the presence of ash in airspace in the vicinity of airports disrupted operations by reducing visibility for safe takeoff and landing and by posing the threat of damage to aircraft. Operations have been curtailed or airports closed when ash is in nearby airspace; the utility of such measures is shown by the instances when aircraft were damaged during approach and takeoff into ash-contaminated airspace. For example, in 1991 at Kumamoto Airport in Japan, a departing airplane was damaged taking off into an ash cloud from Unzen volcano (Casadevall 1993). In 1999, two airplanes on approach to La Aurora International Airport in Guatemala City, Guatemala, were damaged by encountering an ash cloud from Fuego volcano which lies $\sim 40 \mathrm{~km}$ from the airport. In 2000, at least two airplanes heading into Narita International Airport in Tokyo, Japan, were damaged by encountering an ash cloud from Miyake-jima volcano which lies $\sim 180 \mathrm{~km}$ south of Tokyo (Tupper et al. 2004). Also in 2000, an airplane departing the airport at Catania, Italy, was damaged when it encountered ash from Mt. Etna (Coltelli 2006) which lies $30 \mathrm{~km}$ from the airport. During activity at Mt. Etna in 2006, the Catania airport dealt with recurring ash in its airspace by taking the precautionary measure of closing the airport at night for 2 weeks while allowing daytime flights when the whereabouts of the ash were more discernible. During the 1995-1996 eruption of Ruapehu, air space restrictions around the volcano and environs were placed on flying at night and in cloud, and the resulting re-routing increased flight times and thus fuel costs; because the restricted zones were continually adjusted by the civil aviation authority, frequent pilot briefings were required (Johnston et al. 2000).

Ash in airspace can result from remobilization of previously deposited ash. A notable example of this phenomenon occurred after the large 1991 eruption of Hudson volcano in Chile. The ash produced by the eruption was carried to the east by prevailing winds, and ashfall occurred widely in Argentina. In addition to the initial ashfall, strong surface winds in Argentina's arid Patagonia region then resuspended ash for months after the eruption, causing reduced visibility and flight cancellations on several occasions (Casadevall 1993).

On a few occasions, airports have been damaged by volcanic products other than ash. In 1997, W. H. Bramble Airport on the small island of Montserrat in the British West Indies was overrun and destroyed by pyroclastic flows from eruptions of Soufriere Hills volcano. In 2002, the runway at Goma International Airport in the Democratic Republic of the Congo was inundated by lava flows from the eruption of Nyiragongo volcano. In 1957, a phreatic explosion blew a crater in the tarmac of a U.S. military field at Iwo-jima, Japan, and cumulative fault displacements of up to several meters caused older runways to be abandoned (Corwin and Foster 1959).

\subsection{Effects on airports}

The effects of volcanic activity on airports include disruption of operations, damage to aircraft, and damage to facilities. The most common effect is temporary operational disruption, ranging from flight cancellations to airport closures for periods of hours to weeks. The number of days that airports have been closed is not well reported; the longest temporary closures reported are 18 days at Bandung Airport in Indonesia during the 1982 eruption of Galunggung and 15 days at Grant County Airport in Washington State, USA, after the 18 May 1980 eruption of Mt. St. Helens. Rarely, buildings, runways, and other physical infrastructure are destroyed or airports permanently closed. A notable case of physical damage and semi-permanent closure occurred at the airport on Miyake-jima Island, Japan, as a result of eruptive activity in August 2000 that forced the evacuation of 
the island's $\sim 4,000$ residents; subsequent high levels of sulfur dioxide degassing kept the airport closed until mid-2008.

The size of the affected airports varies from major international airports that handle thousands of passengers and substantial cargo tonnages per day, such as Ted Stevens Anchorage International Airport in Alaska, USA, to regional airfields that, while much smaller, nevertheless may be critical transportation infrastructure in some countries, particularly multi-island countries such as Papua New Guinea (Innes 2004).

Several airports have been affected repeatedly by volcanic activity. Four airports have been disrupted on at least five occasions: Fontanarossa International Airport in Catania, on the island of Sicily in Italy; Tokua Airport in Kokopo, Papua New Guinea; Ted Stevens Anchorage International Airport in Alaska, USA; and Mariscal Sucre International Airport in Quito, Ecuador. Although Catania's airport has been affected by ash hazards only from Mt. Etna, the frequently active volcano is close $(\sim 30 \mathrm{~km})$ to the city. The volcano's explosive activity in 2002-2003 was very disruptive, causing repeated closures of Fontanarossa International Airport and complicating travel to mainland Italy (Coltelli 2006). Tokua Airport in Papua New Guinea also has been impacted repeatedly since 1994 by only one nearby, frequently explosive volcanic center, Rabaul caldera. Anchorage's busy international airport and nearby military airports at Elemendorf Air Force Base and Merrill Field are vulnerable, because they are downwind of many active Alaskan volcanoes. Similarly, Quito's airport, located in the inter-Andean basin, is exposed to ash hazards from several Ecuadorian volcanoes that have been very active since 1999.

A few airport locations have been permanently abandoned as the result of volcanic activity. As noted previously, W. H. Bramble Airport (also known as Blackburne Airport) was overrun in June 1997 by pyroclastic flows from an eruption of Soufriere Hills volcano, located a mere $1.3 \mathrm{~km}$ from the airport. Between 1997 and 2005, the island of Montserrat was accessible only by helicopters and boats until Gerald's Airport was built on the north end of the island, protected from future pyroclastic flows by a natural barrier of older volcanic hills. On the island of New Britain in Papua New Guinea, the September 1994 eruption from volcanic cones within Rabaul caldera caused the evacuation of Rabaul town (Blong and McKee 1995), and the airport was relocated to a distance of $\sim 10 \mathrm{~km}$ to the town of Kokopo.

The number of airports impacted annually by volcanic activity has ranged from 0 to 16 per year (Fig. 3). The highest annual value of 16 in 1991 results from the uncommon occurrence in a single year of two very large eruptions (Mt. Pinatubo, VEI 6, and Hudson, VEI 5), but the other high values of 13 and 15 result from the typical occurrence of several small to moderate eruptions in a year. The rise in the annual number of affected airports since 1980 likely reflects more thorough reporting about both global volcanic activity (a factor noted by Simkin and Siebert 1994) and transportation topics. To account for the more reliable data reporting in recent years, we calculate the average annual frequency of affected airports based on data since 1980. On average, five airports per year have been impacted by volcanic activity, which indicates that the volcanic hazard to airports is not rare on a worldwide basis.

\subsection{Source volcanoes}

The 46 source volcanoes that have caused the documented incidents are located in 18 countries (Table 2). Indonesia, the USA, and Japan have the most volcanoes (seven, five, and five, respectively) whose eruptions have impacted airports. Nine volcanoes have been the most troublesome, defined here as causing five or more incidents by more than one 


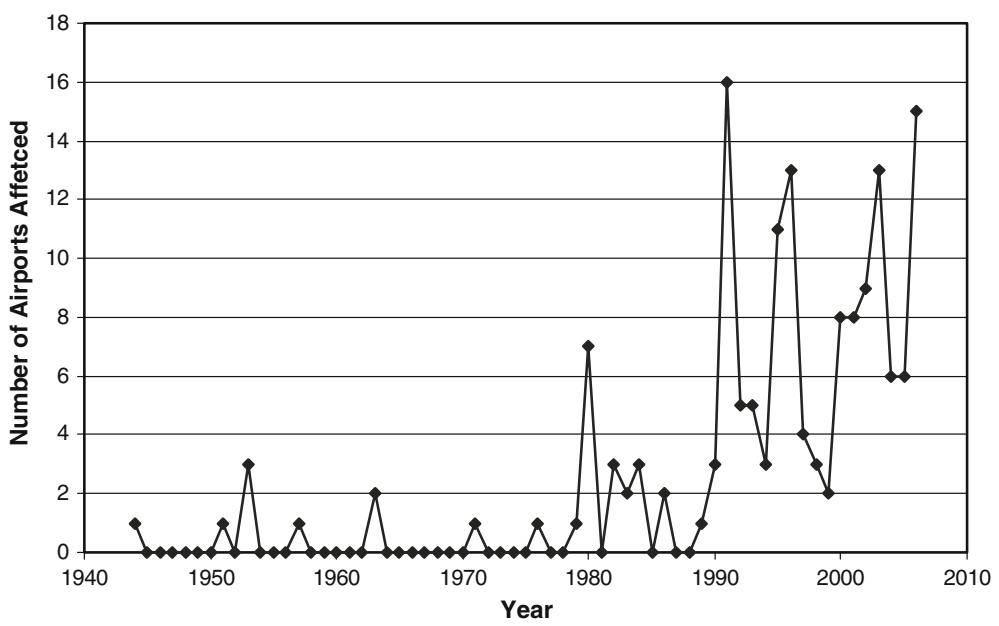

Fig. 3 Graph of number of airports impacted by volcanic activity annually, 1944-2006 (An airport is counted only once per year.)

Table 2 Source volcanoes of eruptions known to have affected airports, 1944 through 2006, organized by country

\begin{tabular}{|c|c|c|c|}
\hline Country & N3 & Source volcano(es) & N4 \\
\hline Chile & 3 & Hudson (5), Llaima (1), Lascar (4) & 10 \\
\hline Colombia & 1 & Galeras (2) & 2 \\
\hline Comoros & 1 & Karthala (1) & 1 \\
\hline Costa Rica & 1 & Irazu (1) & 1 \\
\hline $\begin{array}{l}\text { Democratic Republic } \\
\text { of the Congo }\end{array}$ & 1 & Nyiragongo (1) & 1 \\
\hline Ecuador & 3 & Pichincha (2), Reventador (1), Tungurahua (12) & 15 \\
\hline Guatemala & 2 & Fuego (1), Pacaya (3) & 4 \\
\hline Iceland & 1 & Grimsvotn (1) & 1 \\
\hline Indonesia & 7 & $\begin{array}{l}\text { Agung (1), Awu (1), Egon (1), Galunggung (4), Gamalama (1), } \\
\text { Lokon (3), Soputan (2) }\end{array}$ & 13 \\
\hline Italy & 2 & Etna (11), Vesuvius (1) & 12 \\
\hline Japan & 5 & Asama (1), Iwo-jima (1), Mijake-jima (2), Sakura-jima (3), Unzen (1) & 8 \\
\hline Mexico & 3 & El Chichon (2), Colima (2), Popocatepetl (4) & 8 \\
\hline New Zealand & 2 & Ruapehu (20), White Island (1) & 21 \\
\hline Papua New Guinea & 4 & Lamington (1), Manam (2), Pago (1), Rabaul (7) & 11 \\
\hline Philippines & 3 & Canlaon (1), Mayon (3), Pinatubo (8) & 12 \\
\hline Russia & 1 & Sheveluch (1) & 1 \\
\hline UK (Br. W. I.) & 1 & Soufriere Hills (24) & 24 \\
\hline USA & 5 & Augustine (3), Redoubt (3), Spurr (7), St. Helens (8), Anatahan (5) & 26 \\
\hline Total & 46 & Total & 171 \\
\hline
\end{tabular}

$\mathrm{N} 3$ is the number of source volcanoes in each country that have caused documented incidents at airports. Number in parentheses after each volcano is the number of incidents caused by activity at that volcano. N4 is the number of incidents caused by a country's volcano(es) 
eruptive event: Soufriere Hills volcano on Montserrat, British West Indies; Tungurahua volcano in Ecuador; Mt. Etna in Italy; Rabaul caldera in Papua New Guinea; Mt. St. Helens in the USA; Mt. Spurr in the USA; Ruapehu in New Zealand; Mt. Pinatubo in the Philippines; and Anatahan volcano in the Northern Mariana Islands (a commonwealth of the USA). Soufriere Hills stands out as responsible for the most incidents (24) affecting the most airports (17) owing to the volcano's sustained, frequently explosive eruptive activity since 1995 and proximity to many other islands with airports. The effect of Ruapehu's 20 weeks of sustained phreatomagmatic activity in 1995 and 1996 was on nearly the same scale-20 incidents involving 11 airports, but all within New Zealand. Tungurahua in Ecuador, responsible for 12 incidents since 2000, also is notable for posing a recurring hazard to the region's airports. (Hudson volcano in Chile caused numerous incidents, but as the result of only one very large eruption in 1991.)

A critical factor in determining whether an ash-producing eruption will affect a specific airport is the wind field at the time of the eruptive event. For example, Portland International Airport in Oregon, USA, which lies $75 \mathrm{~km}$ southwest of Mount St. Helens, was spared ash accumulation from the volcano's 18 May 1980 eruption when winds were from the west, only to be disrupted by eruptive events on two occasions in the following months when winds were from the east. For eruptions of long duration, seasonal wind variations may increase the likelihood that an airport will be affected. For example, during much of the eruptive activity at Anatahan volcano in 2003-2005, prevailing trade winds in the South Pacific dispersed ash in westerly directions, away from population centers lying south of the volcano. However, winds in the Marianas region do not blow exclusively to the west, and typhoon winds on 23 May 2003 pushed the ash south, dusting Saipan and causing flight cancellations there and at Guam, $320 \mathrm{~km}$ south of the volcano (Guffanti et al. 2005).

Distances of affected airports from the volcanic sources range from 1 to $2,911 \mathrm{~km}$. Onefifth $(20 \%)$ of airports are within $30 \mathrm{~km}$ of the volcanic sources, about half $(54 \%)$ are within $150 \mathrm{~km}$, and about three-quarters (73\%) are within $300 \mathrm{~km}$; nearly one-fifth (18\%) are more than $500 \mathrm{~km}$ from the source volcanoes (Fig. 4). The two cases of distances

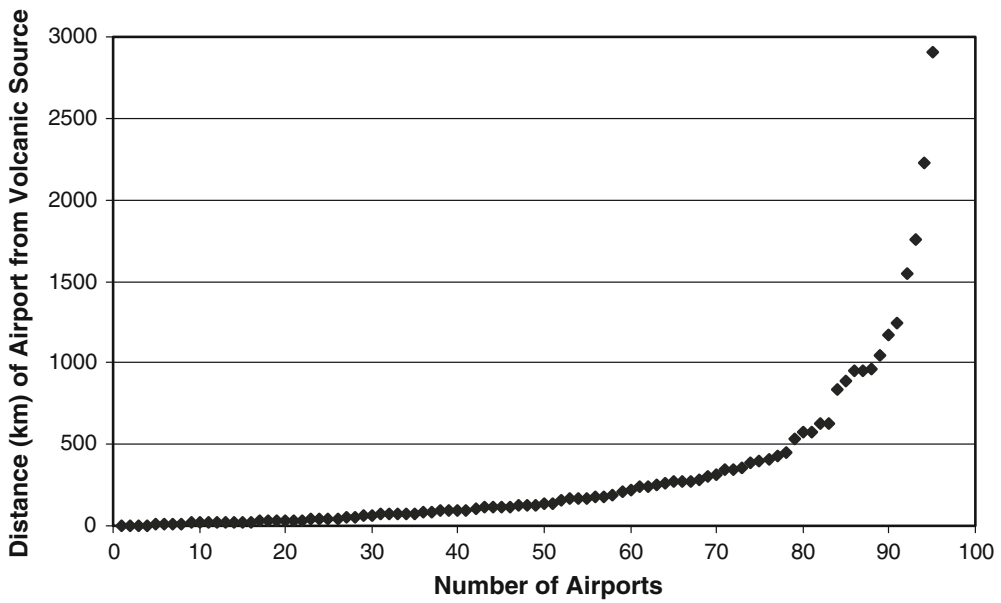

Fig. 4 Distribution of airport distances from volcanic sources (each airport counted once). One-fifth of the airports are within $30 \mathrm{~km}$ of the volcanic sources, about half $(54 \%)$ are within $150 \mathrm{~km}$, about three-quarters $(73 \%)$ are within $300 \mathrm{~km}$, and $82 \%$ are within $500 \mathrm{~km}$ of the source volcanoes. Cumulative number of airports $=95$ (total of 101 airports minus 6 airports with no or uncertain distance data) 
greater than 2,000 km involve ash in airspace, not ashfall; however, ashfall has occurred at airports at distances as great as 1,758 km (1963 VEI 5 eruption of Agung, Indonesia) and $1,543 \mathrm{~km}$ (1991 VEI 5 eruption of Hudson, Chile).

The sizes of eruptions that have impacted airports range from small to very large, as indicated by VEI. As with natural hazards generally, small eruptive events are more common than larger ones; massively large eruptions (VEI 7-8) are very infrequent, recurring on the order of 10,000-100,000 years (Simkin and Siebert 1994). Using VEI values primarily as reported in the Smithsonian Institution's global volcanism database (http://www.volcano.si.edu/), small eruptions (VEI 1-2) were responsible for $16 \%$ of the incidents in the database, moderate eruptions (VEI 3-4) for 68\%, and large eruptions (VEI 5-6) for 14\%. Moderate-sized eruptions, which have affected airports more than 1,000 km away from the volcanic sources, cause the most disruptions both because they occur fairly frequently and because they are large enough to have substantial "reach" in terms of ash dispersal.

\subsection{Hazard and risk}

The data in Tables 1 and 2 can be used to define volcanic hazard and risk measures for airports. The number of a country's volcanoes that have caused incidents (N3 in Table 2) is a volcanic hazard measure for airports-i.e., it is related to the occurrence of the hazardous volcanic phenomenon. The number of a country's airports affected (N1 in Table 1), the number of incidents at all airports in a country (N2 in Table 1), and the number of incidents caused anywhere by a country's volcano/es (N4 in Table 2) are airport vulnerability measures - -i.e., they are related to the people, property, and commerce at risk from the hazardous phenomena. Table 3 summarizes hazard and vulnerability measures for 10 of the 28 countries in which airports were affected. The 10 countries-USA, New Zealand,

Table 3 Summary for selected countries of data on the volcanic hazard measure (N3 from Table 2) and vulnerability measures (N1 and N2 from Table 1, N4 from Table 2) for airports

\begin{tabular}{|c|c|c|c|c|}
\hline \multirow[t]{2}{*}{ Country } & \multirow{2}{*}{$\begin{array}{l}\text { Hazard measure } \\
\text { Number } \\
\text { of source } \\
\text { volcanoes } \\
\text { (N3) }\end{array}$} & \multicolumn{3}{|c|}{ Vulnerability measures } \\
\hline & & $\begin{array}{l}\text { Number } \\
\text { of airports } \\
\text { affected (N1) }\end{array}$ & $\begin{array}{l}\text { Number } \\
\text { of incidents } \\
\text { at the affected } \\
\text { airports (N2) }\end{array}$ & $\begin{array}{l}\text { Number of } \\
\text { incidents caused } \\
\text { by source } \\
\text { volcanoes (N4) }\end{array}$ \\
\hline USA & 5 & 17 & 33 & 26 \\
\hline New Zealand & 2 & 11 & 21 & 21 \\
\hline Indonesia & 7 & 8 & 13 & 13 \\
\hline Ecuador & 3 & 7 & 15 & 15 \\
\hline Philippines & 3 & 8 & 12 & 12 \\
\hline Papua New Guinea & 4 & 6 & 11 & 11 \\
\hline Italy & 2 & 4 & 12 & 12 \\
\hline Japan & 5 & 5 & 8 & 8 \\
\hline Mexico & 3 & 5 & 8 & 8 \\
\hline United Kingdom (Montserrat) & 1 & 3 & 6 & 24 \\
\hline
\end{tabular}

Order of countries is by sum of N1, N2, and N3 
Indonesia, Ecuador, Papua New Guinea, Italy, Philippines, Mexico, Japan, and United Kingdom (Montserrat) — have the highest airport hazard and/or vulnerability measures related to volcanic activity (defined as at least one source volcano and a sum of N1, N2, and $\mathrm{N} 3$ of at least 10).

The USA is notable for having the most airports (17) affected by volcanic activity on the most occasions (33) and the second highest number of source volcanoes (5), which is not surprising given the diverse regions of active volcanism encompassed by the large expanse of the country and its commonwealth and trust territories. The fact that N4 is less than N2 for the USA indicates that airports in the USA have been affected by non-U.S. volcanic activity (specifically, by Soufriere Hills, Montserrat). Conversely, for the United Kingdom N4 is greater than N2, reflecting that its source volcano, Soufriere Hills, has affected airports in other countries.

Published data about costs incurred as a result of the effects of volcanic activity on airports are scarce. Tuck et al. (1992) investigated the economic consequences of the 1989-1990 eruption of Mt. Redoubt in Alaska, USA. A minimum loss of US \$21 million (US \$34.6 million in 2008 dollars) was estimated for the economic impact to Anchorage International Airport between December 1989 and January 1990, based on analysis of disruptions to passenger and freight traffic, airport revenues, and aviation-support industries (2008 dollars calculated in April 2008 using Consumer Price Index conversion at http://woodrow.mpls.frb.fed.us/Research/data/us/calc/).

Since 1989, the airport has grown significantly and become a major hub for international air travel to Asian countries. According to the U.S. Bureau of Transportation Statistics (http://www.bts.gov/), in 2003 Anchorage's airport ranked first (by landed weight) as a cargo hub among all U.S. air gateways, moving $26 \%$ of the tonnage of U.S. international air freight (worth $\$ 22$ billion).

Rodriguez (2004) reported data on the economic impact at Mexico City International Airport from eruptions of Popocatepetl volcano, located $67 \mathrm{~km}$ from the airport. As a result of an eruptive event on 30 June 1997, the airport was closed for $10 \mathrm{~h}$, and several planes were damaged, causing losses of US \$5 million primarily to airline companies (US \$6.7 million in 2008 dollars). A smaller eruptive event at Popocatepetl on 19 July 2003 closed the airport for $6 \mathrm{~min}$ and caused a loss to airline companies of US \$19,250 (US \$22,000 in 2008 dollars).

Anecdotal evidence also indicates significant economic consequences that have occurred owing to volcanic ash. In Ecuador, closures and restrictions at Quito's Mariscal Sucre International Airport were particularly adverse for flower growers who were unable to export their perishable crop to international markets via air cargo, and the tourist sector lost approximately US \$1.5 million per day when activity at Guagua Pichincha in October and November 1999 disrupted the airport (Patricia Mothes, personal communication 2003). As noted by Innes (2004), the island nation of Papua New Guinea has limited road and railway access and is highly reliant on air service for routine passenger travel and cargo transport. Accordingly, the presence of volcanic ash at or near airports there invariably causes major disruption to regular travel, tourism, and the seafood and agricultural industries, with effects that can last for weeks to months. In Italy, Mt. Etna's disruption of flights using Catania's airport, which handled 45,000 landings and takeoffs in 2002 involving four million passengers, reverberated throughout Italy's regional air-route structure (A. Bardaro, oral communication 2003).

Although spotty, the economic data clearly show that mitigation measures that lessen closure times or reduce damage to aircraft at affected airports can prevent significant losses to airport operators, airlines, travelers, and businesses. 


\section{Mitigation}

The effects of volcanic activity on airports can be mitigated by measures such as moving or covering parked aircraft and other equipment, conducting clean-up quickly and efficiently to reduce closure time, optimizing runway usage before and during eruptive events, and modifying approach and take-off routes to avoid ash in nearby airspace.

An important aspect of mitigation efforts to reduce airport vulnerability to volcanic hazards is preparedness, especially by formulation of an airport-specific operational plan. Ideally, such a plan describes methods and available equipment for clean-up, procedures for incorporating up-to-date information from the relevant volcanological agency into operational decisions, protocols for making the decision to close an airport to ensure aircraft and passenger safety, and procedures for managing air traffic in ash-contaminated airspace in the vicinity of the airspace. Airports known to have formulated some type of operational plan include Ted Stevens Anchorage International Airport and Portland International Airport in the USA, Fontanarossa International Airport and Sigonella Naval Air Station in Italy, Mariscal Sucre International Airport in Ecuador, Kagoshima International Airport in Japan, and Auckland International Airport in New Zealand.

The effectiveness of mitigation measures is improved when airports receive forewarning of imminent volcanic hazards. For example, on 18 August 1992, the Alaska Volcano Observatory notified Elmendorf Air Force Base by phone that an eruption of Mt. Spurr was underway and that winds would carry ash toward the base. By the time ashfall commenced at Elmendorf approximately $2 \mathrm{~h}$ later, the base had evacuated, sheltered, or sealed 104 aircraft and released non-critical personnel from duty (Casadevall 1993). Similarly in the Philippines in 1991, advance warning from on-site volcanologists allowed the U.S. Air Force at Clark Air Base to evacuate jet aircraft before the first explosive eruption of Pinatubo on 12 June 1991 (Casadevall 1993).

Examples of techniques that have been used effectively to forewarn airports of volcanic activity include real-time monitoring of explosive volcanoes; forecasts of ash dispersion and deposition; and detection of approaching ash clouds using ground-based Doppler radar.

\subsection{Real-time monitoring}

An example of real-time monitoring of explosive volcanic activity to forewarn an airport is the system at Sakura-jima volcano, Japan, which lies only $10 \mathrm{~km}$ from Kagoshima City's airport (Onodera and Kamo 1994). The volcano's frequent eruptive events are monitored with continuously transmitting seismic and infrasonic instruments designed to distinguish explosive, ash-producing eruptions from volcanic earthquakes and tremor without ash production. When the monitoring system detects an explosive eruption, a warning is automatically sent to flight dispatchers at Kagoshima International Airport. Dispatchers then check wind data and visibility and rapidly issue a recommendation to pilots (i.e., divert to another airport, maintain holding position, select alternate arrival route, or select normal arrival route). The monitoring/warning system used at Sakura-jima has proven very effective at reducing risks to aviation in an unfavorable volcanic environment.

\subsection{Ash dispersion and deposition forecasts}

Various ash transport and dispersion models are used operationally to provide forecasts of airborne ash-cloud movement to aviation users (e.g., McCrady et al. 2004; Stunder and 
Heffter 2004; Watkin et al. 2004; Papp et al. 2005). Dispersion models that also forecast ash deposition on the ground (ashfall) are especially pertinent to the needs of airport operators, among other users. Recently, for example, the U.S. Geological Survey (USGS) Cascade Volcano Observatory (CVO) has produced ashfall forecasts in an operational environment (based on wind forecasts from NOAA and the ash dispersion and deposition model of Hurst 1994) for an actual eruption of Anathan and for hypothetical eruptions of Mt. St. Helens. In the case of Anatahan, an eruptive event on 5 April 2005 sent ash to nearly $16 \mathrm{~km}$ which then dispersed toward the island of Saipan, $120 \mathrm{~km}$ south of the volcano. Saipan residents observed the dark ash cloud approaching overhead, prompting a request to the USGS for an assessment of expected ash accumulation. Model results indicated potential for only minor ashfall on Saipan, including at the airport, and CVO quickly relayed that information by telephone to the community's emergency management office, preventing undue concern and unnecessary precautions (Guffanti et al. 2006). For Mount St. Helens, which returned to an eruptive state in 2004 after 18 years of quiescence, CVO has produced ashfall-scenario maps twice daily for hypothetical eruptions, using numerical forecast winds from NOAA and pre-selected values for volcanological parameters such as erupted volume and plume height (Ewert et al. 2006). The maps were provided to the Washington State Emergency Management Division and the Air Force Weather Agency for distribution to local entities, including operators of the numerous military and commercial airports in the region, had the need arisen to assess where ashfall would occur. A similar approach of providing daily ash dispersion and deposition scenarios for hypothetical or actual eruptions of Mt. Etna is being developed for operational use (Barsotti et al. 2006; Coltelli 2006).

As further progress is made in development of ash dispersion and deposition models, some features can improve the readiness of meteorological services and airport operators in vulnerable areas. (1) There is a need for the capability to forecast when ashfall will commence and end at a particular location, as well as how much ash accumulation is expected. During an eruption, awareness of the time window still open for normal operations before ash arrives can help an airport operator minimize runway restrictions and prioritize preparedness measures, while knowing when ashfall is expected to end can help airport operators make decisions about staffing, approaching aircraft, and clean-up procedures. (2) During periods of premonitory volcanic unrest or eruptive pauses, ashfall scenarios should be issued on a regular schedule, and this function may need to be conducted routinely for an extended length of time (many months). (3) Models should work well with minor eruptions that emit small volumes of material for less than an hour and have little distal ashfall, as well as handle large eruptions that eject great amounts of ash into the stratosphere for hours to days, producing significant ashfall up to hundreds of kilometers away. (4) In all cases of actual eruptions, observations of column height and eruption duration should be sought out and incorporated into the model runs to provide realistic results. (5) Lastly, the above-mentioned features should be incorporated into a model (or suite of models) that can be run operationally in real-time by staff at volcanological agencies and/or weather services.

Even without thorough dispersion and deposition modeling, analysis of archived windfield data can be useful to determine if a particular airport is at long-term risk because it lies within the predominant yearly (or longer) downwind direction from nearby active volcanoes. Archived global wind data sets for such an analysis are available through NOAA at http://www.cdc.noaa.gov/cdc/data.ncep.reanalysis.html and from the European Center for Medium Range Weather Forecast (ECMWF) data at http://www.ecmwf.int/ products/data/archive/descriptions/e4/index.html. 


\subsection{Ground-based radar}

Weather radar has proven useful in detecting and characterizing volcanic-ash plumes (see, for example, Harris et al. 1981; Rose and Kostinski 1994; Rose et al. 1995; Oswalt et al. 1996; Lacasse et al. 2004; Hendricks 2006; Marzano et al. 2006; Schneider et al. 2006). Radar is useful for estimating plume heights and ash-particle sizes; with Doppler capability, radar also can provide information about the direction and speed of ash dispersion. Radar observations of eruptive phenomenon are available instantly and can be made at night and in poor weather conditions. Ground-based weather radar units often are located at or near airports and may be situated to observe a nearby volcano. Although radar operated for meteorological monitoring is not ideal for observing ash clouds $\left(360^{\circ}\right.$ volumetric scanning can take up to $10 \mathrm{~min}$ and various settings may not be optimized for detecting ash), utilizing available weather radar in cooperation with the appropriate meteorological agency may be a beneficial option for some airports.

An experiment that customized the use of radar for detecting ash hazards to aviation is described by Hoblitt and Quaas Weppen (1999). In 1997-1998, Mexico's National Center for the Prevention of Disasters (CENAPRED) and the USGS deployed an experimental ground-based Doppler radar in Mexico City to track the height, direction, and speed of ash plumes from Popocatepetl volcano approximately $60 \mathrm{~km}$ away. The radar unit constantly scanned the volcano, and seismic data were collected and analyzed in conjunction with the radar data. Simultaneous occurrence of a seismic event and a strong reflected radar signal initiating over the volcano provided incontrovertible evidence that an explosive event had occurred and that ash was in the air. In such cases, CENAPRED would quickly call Mexico City International Airport to warn air-traffic controllers of imminent ash hazards. The experimental system used in Mexico eventually suffered a hardware failure but clearly demonstrated the utility of dedicated radar combined with seismic data to provide rapid and reliable warnings of ash hazards to aviation.

\section{Conclusions}

Volcanic activity has resulted in significant hazards to numerous airports worldwide, with a recent (since 1980) frequency of approximately five airports affected per year on average. The hazards and risks are geographically dispersed, involving many source volcanoes and affecting airports in more than two dozen countries. The risks are not restricted to airports located close to volcanoes but can affect airports many hundreds of kilometers away. Eruptions do not need to be large to be disruptive; small eruptions have caused one-fifth of the documented incidents, and moderate-size ones have caused nearly two-thirds.

In the future, some airports already affected by volcanic activity will be again, and some as yet untouched airports will be impacted. While it is not possible from this study to assign specific risk factors to each of the world's airports, those airports within $300 \mathrm{~km}$, and in the predominant downwind sectors of an active or recently active explosive volcano can be considered at elevated risk from potential volcanic hazards. An airport can prepare-without major expense-by developing an operational plan for volcanic events and by maintaining contacts with the responsible volcano-monitoring agency. Volcano-monitoring agencies can help vulnerable airports by directly contacting them with timely eruption forecasts and reports and, if possible, by forecasting when and where ash dispersion and deposition are likely to occur for a particular eruption. 
Volcanic activity will continue to threaten airports, but with foresight and diligence some of the adverse effects can be lessened to the benefit of travelers and commerce. Forewarning of imminent volcanic hazards improves the effectiveness of mitigation actions taken by airports. Such forewarning requires that hazardous volcanoes be instrumentally monitored on a real-time basis and that the responsible volcanological agencies develop and test standard operating procedures for notifying airport operators of hazardous volcanic activity. Countries with significant volcanic hazards to airports should strive to meet these basic requirements.

Acknowledgments This work was supported by the USGS Volcano Hazards Program. Chris Newhall, Steve Brantley, and two anonymous reviewers provided helpful reviews of this report.

\section{References}

Barsotti S, Nannipieri L, Neri A (2006) An early-warning system for volcanic ash dispersal-the MAFALDA procedure. Eos Trans AGU 87(52), Fall Meet Suppl, Abstract V21C-06

Blong RJ (1984) Volcanic hazards: a sourcebook on the effects of eruptions. Academic Press Australia, Sydney

Blong R, McKee C (1995) The Rabaul eruption 1994: destruction of a town. Natural Hazards Research Centre, Macquarie University, Australia

Casadevall TJ (1993) Volcanic ash and airports: discussion and recommendations from the workshop on impacts of volcanic ash on airport facilities. US Geological Survey Open-File Report 93-518

Casadevall TJ, Delos Reyes PJ, Schneider DJ (1996) The 1991 Pinatubo eruptions and their effects on aircraft operations. In: Newhall CG, Punongbayan RS (eds) Fire and mud-eruptions and lahars of Mount Pinatubo, Philippines. University of Washington Press, Seattle, pp 1071-1085

Coltelli M (2006) Etna explosive eruptions and the INGV response to improve an ash-cloud monitoring system. In: Abstracts of the fourth conference cities on volcanoes, international association of volcanology and chemistry of the earth's interior, Quito, 23-27 Jan 2006, p 19

Corwin G, Foster HL (1959) The 1957 explosive eruption on Iwo Jima, Volcano Islands. Am J Sci 257: $161-171$

Ewert JW, Griswold J, Wardwell RS, Bohlander A (2006) Communicating potential ash-fall hazards with scenario maps at Mount St. Helens. Eos Trans AGU 87(52), Fall Meet Suppl, Abstract V33B-0657

Guffanti M, Casadevall TJ, Mayberry GC (2004) Reducing encounters of aircraft with volcanic-ash clouds. In: Proceedings of the 2 nd international conference on volcanic ash and aviation safety, NOAA Office of the Federal Coordinator for Meteorology, Alexandria, 21-24 June 2004, pp 1/17-21

Guffanti M, Ewert JW, Swanson G, Gallina G, Bluth G (2005) The volcanic-ash hazard to aviation during the 2003-2004 eruptive activity of Anatahan volcano, Commonwealth of the Northern Mariana Islands. J Volcanol Geotherm Res 146:241-255

Guffanti M, White R, Ewert J, Lockhart A, Koyanagi S (2006) Practical ash-hazard information for the aviation sector: examples from the 2003-2005 eruptive activity of Anatahan, Northern Mariana Islands. In: Abstracts of the fourth conference cities on volcanoes, international association of volcanology and chemistry of the earth's interior, Quito, 23-27 Jan 2006, p 23

Guffanti M, Mayberry GC, Wunderman R, Casadevall TJ (2007) Database of disruptions to airports by volcanic activity. US Geological Open-File Report 2007-1256

Harris DM, Rose WI, Roe R, Thompson MR (1981) Radar observations of ash eruptions. In: US Geological Survey professional paper 1250, pp 323-333

Hendricks TP (2006) Early detection of the 5 April 2005 Anatahan volcano eruption using the Guam WSR88D. Natl Weather Assoc J Oper Meteorol 2006-EJ8. http://www.nwas.org/ej/2006/2006.html. Accessed 28 April 2008

Hoblitt RP, Quaas Weppen R (1999) Doppler radar as a volcano monitoring tool. In: Abstracts of the international symposium on Popocatepetl volcano, Mexico City, 22-24 March 1999, p 19

Hurst AW (1994) ASHFALL - a computer program for estimating volcanic ash fallout, report and users guide. Institute of Geological and Nuclear Sciences Science Report 94/23, Wellington

Innes D (2004) Air Niugini and the volcanic ash threat. In: Proceedings of the 2nd international conference on volcanic ash and aviation safety, NOAA Office of the Federal Coordinator for Meteorology, Alexandria, 21-24 June 2004, pp 1/15-16 
International Civil Aviation Organization (2001) Manual on volcanic ash, radioactive material, and toxic chemical clouds: Doc 9691-AN/954

Johnston DM, Houghton BF, Neall VE, Ronan KR, Paton D (2000) Impacts of the 1945 and 1995-1996 Ruapehu eruptions, New Zealand: an example of increasing societal vulnerability. Geol Soc Am Bull 112:720-726

Lacasse C, Karlsdottir S, Larsen G, Soosalu H, Rose WI, Ernst GGJ (2004) Weather radar obervations of the Hekla 2000 eruption cloud, Iceland. Bull Volcanol 66:457-473

Marzano FS, Barbieri S, Vulpiani G, Rose WI (2006) Volcanic ash cloud retrieval by ground-based microwave weather radar. IEEE Trans Geosci Remote Sens 44:3235-3246

McCrady M, Trudel S, Gauthier, JP, Servranckx R (2004) The Montreal VAAC toolbox-when every second counts. In: Proceedings of the 2 nd international conference on volcanic ash and aviation safety, NOAA Office of the Federal Coordinator for Meteorology, Alexandria, 21-24 June 2004, p 4/53. http://www.ofcm.noaa.gov/ICVAAS/Proceedings2004/ICVAAS2004-Proceedings.htm. Accessed 28 April 2008

Miller TP, Casadevall TJ (2000) Volcanic ash hazards to aviation. In: Sigurdsson H (ed) Encyclopedia of volcanoes. Academic Press, San Diego

Onodera S, Kamo K (1994) Aviation safety measures for ash clouds in Japan and the system of Japan Air Lines for monitoring eruptions at Sakurajima volcano. US Geol Surv Bull 2047:213-219

Oswalt JS, Nichols W, O'Hara JF (1996) Meteorological observations of the 1991 eruption of Mount Pinatubo eruption. In: Newhall CG, Punongbayan RS (eds) Fire and mud-eruptions and lahars of Mount Pinatubo, Philippines. University of Washington Press, Seattle, pp 625-636

Papp KP, Dean KG, Dehn J (2005) Predicting regions susceptible to high concentrations of airborne volcanic ash in the North Pacific region. J Volcanol Geotherm Res 148:295-314. doi:10.1016/j. jvolgeores.2005.04.020

Rodriguez H (2004) Volcanic ash impact on international airport of Mexico City (AICM) due to emissions of Popocatepetl volcano. In: Proceedings of the 2nd international conference on volcanic ash and aviation safety, NOAA Office of the Federal Coordinator for Meteorology, Alexandria, 21-24 June 2004, pp 4/15-17

Rose WI, Kostinski AB (1994) Radar remote sensing of volcanic ash clouds. US Geol Surv Bull 2047: 391-396

Rose WI, Kostinski AB, Kelley L (1995) Real-time C-band radar observations of 1992 eruption clouds from Crater Peak, Mount Spurr volcano, Alaska. US Geol Surv Bull 2139:19-26

Schneider DJ, Scott C, Wood J, Hall T (2006) NEXRAD weather radar observations of the 2006 Augustine volcanic eruption clouds. Eos Trans AGU 87(52), Fall Meet Suppl, Abstract V51C-1686

Simkin T, Siebert L (1994) Volcanoes of the world. Geoscience Press, Tucson

Stunder BJB, Heffter JL (2004) Volcanic ash dispersion modeling research at NOAA Air Resources Laboratory. In: Proceedings of the 2nd international conference on volcanic ash and aviation safety, NOAA Office of the Federal Coordinator for Meteorology, Alexandria, 21-24 June 2004, pp 3/105110. http://www.ofcm.noaa.gov/ICVAAS/Proceedings2004/ICVAAS2004-Proceedings.htm. Accessed 28 April 2008

Tuck BH, Huskey L, Talbot L (1992) The economic consequences of the 1989-90 Mt. Redoubt eruptions. University of Alaska Anchorage, Institute of Social and Economic Research

Tupper A, Kamada Y, Todo N, Miller E (2004) Aircraft encounters from the 18 August 2000 eruption at Miyake-jima, Japan. In: Proceedings of the 2nd international conference on volcanic ash and aviation safety, NOAA Office of the Federal Coordinator for Meteorology, Alexandria, 21-24 June 2004, pp $1 / 5-9$

Watkin S, Karlsdottir S, Gait N, Ryall D, Watkin H (2004) Volcanic ash monitoring and forecasting at the London VAAC. In: Proceedings of the 2nd international conference on volcanic ash and aviation safety, NOAA office of the Federal Coordinator for Meteorology, Alexandria, 21-24 June 2004, pp 4/65-69 